\title{
What is the economic burden of sports injuries?
}

\author{
Spor yaralanmalarının ekonomik yükü nedir?
}

\author{
Selcen Öztürk, MSc, PhD., Dilek Kılıç, MSc, PhD. \\ Department of Economics, Faculty of Economics and Administrative Sciences, Hacettepe University, Ankara, Turkey
}

\begin{abstract}
Despite the health benefits of sports activities, sports injury and fear of injury are important barriers to participation in sport. The incidence, prevalence and type of sports injuries vary among men and women as well as age groups. It is usually difficult to examine these different aspects of sports injuries due to insufficient data. This study argues that sport injuries can be considered as an important economic burden in terms of the direct and indirect costs it bears. As a result, strong and effective strategies are needed to prevent sports injuries. Sports medicine has also been attracted increasing attention in recent years, particularly. In this article, the importance of sports injuries and their economic costs as well as the role of sport medicine as a prevention method for sports injuries were discussed.

Key words: Cost benefit analysis; economics of sport; health economics; sport injuries; sport medicine.
\end{abstract}

Sports, sports injuries and sports medicine are among the modern world's exciting topics. These topics are investigated in many areas, such as medicine, physiology, chemistry, pharmacology, sociology and economics. ${ }^{[1-5]}$ In the modern day economy, sports are now seen as an industry. Professional teams are profit-maximizing firms which are also active on the stock markets. Team sports can now be searched using classical microeconomic tools. ${ }^{[5]}$ The sports industry can be diversified into two main branches-- the sports goods industry which is a segmented/innovative market and sports services. Sports services can be further divided into two branches, attending and watching. ${ }^{[6]}$
Sağlık üzerindeki olumlu faydalarına rağmen, spor yaralanmaları ve yaralanma korkusu spor aktivitelerine katılım önündeki önemli engeller arasındadır. Spor yaralanmalarının sıklığı, yaygınlığı ve türü hem yaş grupları hem de cinsiyetler arasında farklılık göstermektedir. Spor yaralanmalarının bu farklı yönlerini araştırmak bu düzeyde detaylı veri bulunmadığı için genellikle zordur. Bu çalışma, barındırdığı doğrudan ve dolaylı maliyetler nedeniyle spor yaralanmalarının önemli ekonomik yük olarak görülebileceğini öne sürmektedir. $\mathrm{Bu}$ nedenle, spor yaralanmalarının önüne geçilebilmesi için güçlü ve etkili yöntemlere gereksinim vardır. Ayrıca spor hekimliği özellikle son yıllarda oldukça dikkat çekmektedir. Bu yazıda spor yaralanmalarının önemi, bu yaralanmaların ekonomik maliyeti ve yanı sıra spor hekimliğinin spor yaralanmalarını engellemek için kullanılan bir yöntem olarak rolü tartışıldı.

Anahtar sözcükler: Fayda maliyet analizi; spor ekonomisi; sağlık ekonomisi; spor yaralanmaları; spor hekimliği.

The main purpose of this paper is to investigate the importance of sports injuries and their economic costs. In this context, this study is concerned with the attending rather than the watching branch of the sports industry. Attending sports activities as an amateur or professional or solely for exercise is simply a matter of choice that an individual faces during some point in her/his life. An individual must first decide whether or not to attend sporting activities and then decide how much of her/his time she/he will devote to sporting activities. However, increased participation in sport activities should consider the probability of sports injuries, the economic costs of these injuries as well as the strategies to prevent these injuries. ${ }^{[7]}$

- Received: February 04, 2013 Accepted: May 02, 2013

- Correspondence: Selcen Öztürk, MSc, PhD. Hacettepe Üniversitesi İktisadi ve İdari Bilimler Fakültesi, İktisat Bölümü, 06800 Beytepe, Ankara, Turkey. Tel: +90 312 - 2978650 Fax: +90 312 - 2992003 e-mail: selcen@hacettepe.edu.tr 


\section{PHYSICAL ACTIVITY: BENEFITS AND RISKS}

As is well known, there are numerous benefits of exercise/sporting activities on health. Recent work shows physical activity has important positive effects on both physical and mental health. ${ }^{[8]}$ The numbers from all over the world indicate that obesity and sedentary life style is now one of the main concerns of public health. Obesity is seen as an epidemic. Physical activity has positive effects on decreasing obesity, diabetes and cardiovascular diseases. ${ }^{[9]}$

Exercise is often suggested as a disease prevention method. Even though osteoporosis is mainly related to genetic and nutritional factors, it is closely linked to physical activity and exercise. ${ }^{[10]}$

\section{SPORTS INJURIES}

Sports injury ranks among the major public health problems because of its important social and economic burden for society. In order to understand the seriousness of a sports injury, Bahr ${ }^{[1]]}$ offer six criteria for physicians-- nature of sports injuries; diagnosis, duration and nature of the treatment; sports time lost when injured; working or school time lost; permanent disability; and cost of injury.

There are special considerations for pediatric, adolescent, and female athletes in terms of the risk factors of sports injuries they are facing. Youth tend to be more polarized in terms of physical activity and inactivity. There is either no physical activity; hence obesity, or too much activity; hence injuries. The numbers of overuse or stress injuries have been increasing for young athletes. ${ }^{[12]}$ Since the young athlete is a growing child, most common injuries differ from adults. Most common injuries in adolescents are observed in musculoskeletal tissue junctional sites. Further stress fractures are also widely observed in pediatric and adolescent athletes. Knee, shoulder injuries and joint instability are also seen. ${ }^{[12]}$ In this context, exercise is often suggested as a disease prevention method.

On the other hand, there are increasing number of studies focusing on the economic costs of sports injuries since there is a need for determining the costbenefit of preventive measures. Cost of sports injury studies are important for policy makers to prioritize health care resources and research aims for developing injury prevention programs. ${ }^{[13]}$

\section{ECONOMIC APPROACH TO SPORTS INJURIES}

There are two dimensions of sports activities: health benefits associated with physically active lifestyle and related to a risk of injury. As indicated above, the cost of injury is one of the most important indicators for the seriousness of a sports injury. In economic terms, similar to all other injuries, the sports injury costs consists of two main categories-- medical costs or core costs resulting directly from the injury and non-medical costs of the injury such as transportation or health insurance. Each category also has direct and indirect costs. ${ }^{[13]}$

In general, direct costs of an injury are calculated by considering the cost of using health care resources to prevent, detect and treat injury and its complications. In order to calculate this type of cost, there is a need for data on health care utilization and its costs such as the length of hospital stay for a specific injury and the cost per day for that injury. ${ }^{[14]}$ On the other hand, indirect costs indicate the absenteeism from work or the loss of productive output in the economy as a consequence of the injury. The human capital approach is commonly used to calculate the indirect costs of injuries. This method measures the lost production, in terms of lost earnings, by assuming that the value of a human life is equal to its expected (discounted) future income. ${ }^{[14]}$ However, this method is criticized since it may overestimate the cost of production losses by disregarding the worker replacement option. In the short-term, the injured employee's urgent work can be completed by the other workers and nonurgent works can be cancelled or completed by the injured employee when he/she returns to work. In the long-term, the injured worker can be replaced from the pool of unemployed labor or the jobs can be reallocated among the other workers. The friction cost method, introduced by Koopmanschap et al. ${ }^{[15]}$ takes into account the worker replacement option after the friction period when estimating the direct costs of an injury. ${ }^{[15,16]}$ On the other hand, the human capital approach has been criticized because it may also underestimate costs because it values life using market earnings but if a significant part of the study population consists of children and retired elderly, the results will undervalue the real production loss. Furthermore, this method disregards psychological costs and also, there may be labor market imperfections and, in this case, wages are not an appropriate indicator for true

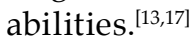

There are also general criticisms for the cost of injury studies since they have shown already-known figures from the health statistics and it is believed that they have little contribution to the existing literature. Moreover, if a particular injury has a higher economic cost, then, it has a priority for prevention 
policy. However, allocating resources to prevent or treat the most costly injury will lead to the loss of benefits that could have been obtained if resources had been devoted for another activity. This indicates an important economic concept known as opportunity cost and implies that it is important to know not only the costs but also benefits of the activity to maximize societal benefits. In this regard, health economics has a crucial role in preventing injuries through the evaluation of the costs and benefits of injury prevention strategies. ${ }^{[14]}$

The primary aim of the costs of sports injury studies is to show the importance of sports injuries in terms of economic costs and also to assess the injury prevention strategies. For example, it has been shown that preseason training, warm up and cool down patterns, using protecting equipment and meeting safety standards are among the factors that reduce sports injuries significantly. ${ }^{[18]}$ However, one particular factor, sports medicine, has widely been emphasized in sports injury prevention studies. Stevenson et al. ${ }^{[19]}$ has found that the risk of injury was reduced by $32 \%$ if the participants had received a program designed by a professional. It should also be stated that sports medicine is of importance, not only as preventive medicine but also for supplying special treatments and cures for specific sports injuries.

\section{SPORTS MEDICINE}

The definition and the scope of sports medicine are evolving every day. Sports medicine was previously related only to elite athletes and professional teams. The modern definition of sports medicine is quite different than the first definition. ${ }^{[20]}$ More recently sports medicine addresses the general population as well as the professionals.

Increasing participation in physical activity means increasing incidence of sports injuries. In this regard, sports medicine has important roles both in preventing injuries and curing them. Even with increasing incidents of sports injuries, it is still clear that the benefits of physical activity outweigh the risks of injuries and furthermore it is possible to minimize the risk factors via preventive medicine.

In order to prevent sport injuries it is quite important to understand the risk factors behind the injuries and the mechanisms that lead to the injury. Furthermore, identifying the magnitude of the problem when it occurs is also important to prevent overuse injuries and to attend the injury when it is minimal. ${ }^{[2]}$ In this context, sports medicine and education for physicians especially family physicians in sports medicine is vital. The education and importance of sports medicine differ between countries. Some countries pay more attention to sports medicine and its education than others. In Brazil, Mexico, Germany, Italy and Spain for instance, sports medicine is recognized by medical societies and universities have separate departments and staff for its education. The United States and Canada, on the other hand, do not offer sports medicine education as a separate program at the undergraduate level, however there is a possibility of fellowship. Finally some countries do not offer separate education programs at any level for sports medicine. A study regarding the United Kingdom and Ireland reveals that $94 \%$ of physicians who took part in the study think that A\&E (accident \& emergency) specialists are trained and appropriate to treat sport injuries. ${ }^{[22]}$

As a result of the increasing attention to sports from the general population, family physicians will obviously have increasing incidents of sports injuries. In terms of identifying the magnitude of the injury and being able to proceed accordingly (referring the patients to an orthopedic surgeon if necessary), physicians need education in sports medicine. Moreover, it is a well-known fact that sports medicine is necessary for both presence and absence of physical activity. As mentioned above, physical inactivity is also a rapidly growing problem for the world and exercise is the most important method to overcome the problem.

Even though exercise, physical activity and sports are gaining more attention every day, sports injuries and sports medicine are still two related topics that are undervalued. Research and data indicate the importance of physical activity. As mentioned above physical activity is closely linked to sports injuries. Minimizing sports injuries are of great importance for two reasons. First of all sports injuries are important for the physically active individual since it will cause the individual either to spend less time in physical activity or to stop completely. Therefore, minimum injury time will allow the individual to get back to the sporting activity of her/his choice and to be able to keep maintaining a healthy lifestyle. The second reason is the cost of injury. As mentioned above sports injuries have direct and indirect costs over production and the health system.

In conclusion, it is possible to say that sports medicine plays an important role for both preventing sports injuries and also in terms of minimizing the comeback time in sports injuries. Preventive sports medicine not only minimizes the sports injury time but also helps to decrease the costs of a sedentary 
life style, via decreasing the risk factors of obesity, diabetes and cardiovascular diseases. However, throughout the world, sports medicine does not receive the required attention in terms of research and more importantly in terms of data.

This study argues that in order to increase participation in sports and hence increase the health benefits of the public, it is important to eliminate the barriers to sporting activities such as the risk factors of sports injuries and in this extent sports medicine plays an important role. Furthermore, from an economic perspective, sports medicine research and data is of importance to both academics and policy makers since it will reveal important information on the cost benefit analysis of a physically healthy lifestyle.

\section{Declaration of conflicting interests}

The authors declared no conflicts of interest with respect to the authorship and/or publication of this article.

\section{Funding}

The authors received no financial support for the research and/or authorship of this article.

\section{REFERENCES}

1. Akkaya S, Serinken M, Akkaya N, Türkçüer İ, Uyanık E. Football injuries on synthetic turf fields. Eklem Hastalik Cerrahisi 2011;22:155-9.

2. Atik OS, Dur H. Unusual tennis injuries: boxer's fracture and medial subtalar dislocation. Eklem Hastalik Cerrahisi 2011;22:180-2.

3. Akkaya S, Akkaya N, Kıter E, Kılıç A, Ardıç F. Functional status, patient satisfaction and quality of life in patients with arthroscopic partial meniscectomy. [Article in Turkish] Eklem Hastalik Cerrahisi 2012;23:9-14.

4. Atik OS. Is the evidence behind platelet-rich plasma therapies strong enough? Eklem Hastalik Cerrahisi 2012;23:1.

5. Ekmekçi YA, Ekmekçi R, İrmiş A. Globalization and the sports industry. Pamukkale J Sports Sciences 2013;4:91-117.

6. Andreff W. The sports good industry. In: Andreff W, Szymanski S, editors. Handbook on the economics of sport. Northampton: Edward Elgar Publishing; 2006. p. 27-40.

7. Stevenson MR, Hamer P, Finch CF, Elliot B, Kresnow M. Sport, age, and sex specific incidence of sports injuries in
Western Australia. Br J Sports Med 2000;34:188-94.

8. Penedo FJ, Dahn JR. Exercise and well-being: a review of mental and physical health benefits associated with physical activity. Curr Opin Psychiatry 2005;18:189-93.

9. OECD, OECD Factbook 2011-2012: Economic, Environmental and Social Statistics, OECD Publishing; 2012. Available from: http://www.oecd-ilibrary.org/economics/oecdfactbook-2011-2012_factbook-2011-en

10. Vuori I, Andersen LB. Exercise as disease prevention. In: Kjaer M, Krogsgaard M, Magnusson P, Engebretsen L, Roos $\mathrm{H}$, Takala $\mathrm{T}$, et al, editors. Textbook of sports medicine. Massachusetts: Blackwell; 2003. p. 315-36.

11. Bahr R, Kannus P, Van Mechelen W. Epidemiology and prevention of sport injuries. In: Kjaer M, Krogsgaard M, Magnusson P, Engebretsen L, Roos H, Takala T, , editors. Textbook of sports medicine. Massachusetts: Blackwell; 2003. p. 299-314.

12. Chang DS, Mandelbaum BR, Weiss JM. Special considerations in the pediatric and adolescent athlete. In: Frontera WR, Herring SA, Micheli LJ, Silver JK, editors. Clinical sports medicine. Philedelphia: Saunders Elsevier; 2007. p. 73-85.

13. Rice DP. Cost of illness studies: what is good about them? Inj Prev 2000;6:177-9.

14. Currie G, Kerfoot KD, Donaldson C, Macarthur C. Are cost of injury studies useful? Inj Prev 2000;6:175-6.

15. Koopmanschap MA, Rutten FF, van Ineveld BM, van Roijen L. The friction cost method for measuring indirect costs of disease. J Health Econ 1995;14:171-89.

16. Cumps E, Verhagen E, Annemans L, Meeusen R. Injury rate and socioeconomic costs resulting from sports injuries in Flanders: data derived from sports insurance statistics 2003. Br J Sports Med 2008;42:767-72.

17. Lindqvist K. Economic impact of injuries according to type of injury. Croat Med J 2002;43:386-9.

18. Nys J. Physical activity, sport and health. In: Andreff W, Szymanski S, editors. Handbook on the economics of sport. Northampton: Edward Elgar Publishing; 2006. p. 141-53.

19. Stevenson M, Finch C, Hamer P, Elliott B. The Western Australian sports injury study. Br J Sports Med 2003;37:380-1.

20. Frontera WR. An overview of sports medicine. In: Frontera WR, Herring SA, Micheli LJ, Silver JK, editors. Clinical sports medicine. Philedelphia: Saunders Elsevier; 2007. p. 3-6.

21. Strother R, Dhanani N, Lockyer J. Education in Sports Medicine: A resident perspective. Can Fam Physician 1990;36:1966-70.

22. Abernethy L, MacAuley D, McNally O, McCann S. How important is sport and exercise medicine to the accident and emergency specialist? A study in the UK and Ireland. Emerg Med J 2003;20:540-2. 